\title{
Current Status and Detection of Genetically Modified Organism
}

\author{
TZU-MING PAN
}

Department of Agriculture Chemistry, National Taiwan University, No. 1, Section 4, Roosevelt Road, Taipei, Taiwan, ROC

(Received: September 30, 2002; Accepted: November 22, 2002)

\begin{abstract}
Production of genetically modified (GM) crops is currently concentrated in just a few countries. In 2001, 99\% of GM crops was produced in four countries: US 68\%, Argentina 11.8\%, Canada 6\% and China 3\%. Crop-wise, GM soybean made up 63\% of global GM planting area and GM corn accounts for $19 \%$, followed by GM cotton (13\%) and GM canola (5\%). In terms of the global planting area, GM soybean and cotton accounted for $46 \%$ and $20 \%$, respectively. Two major genetically modified organisms (GMO) traits in 2001 were herbicide tolerant crops, accounted for $77 \%$ of all GM crops, while Bt maize accounted for $11 \%$.

Legislation enacted worldwide to regulate the presence of GMOs in crops, foods and ingredients, necessitated the development of reliable and sensitive methods for GMO detection. In this article, protein- and DNA-based methods employing western blots, enzymelinked immunosorbant assay, lateral flow strips, Southern blots, qualitative-, quantitative-, real-time- and limiting dilution-PCR methods, are discussed. Where information on modified gene sequences is not available, new approaches, such as near-infrared spectrometry, might tackle the problem of detection of non-approved genetically modified (GM) foods. The efficiency of screening, identification and confirmation strategies should be examined with respect to false-positive rates, disappearance of marker genes, increased use of specific regulator sequences and the increasing number of GM foods.
\end{abstract}

Key words: genetically modified organism (GMO), genetically modified food (GM-food), western blots, enzyme-linked immunosorbant assay (ELISA), lateral flow strips, Southern blots, qualitative-PCR, quantitative-PCR, real-time-PCR, limiting dilution-PCR

\section{INTRODUCTION}

As the world population reached six billion at the end of the last century, several major advancements in crop improvement and breeding technologies such as the Green Revolution propelled a dramatic increase of food productivity. As of today, world food production has reached a level at which everyone on this planet could have enough food ${ }^{(1,2)}$. Even though recent assessment indicates that there is a drastic deceleration in the world demographic growth, the world population has reached six billion at the turn of the new millennium and is projected to reach 8.1 billion in $2030^{(3)}$. Although the world food productivity has improved significantly, an alarming portion of world population is still at the verge of starvation. According to the latest FAO statistics ${ }^{(4)}$, there are 815 million undernourished people in the world. Among them, 777 million live in developing countries. Rather than insufficient food production, today's food insecurity problem is actually closely related to issues of distribution: unequal access and poverty ${ }^{(5)}$.

Biotechnology is by all means the most controversial agricultural technology innovation due to the uncertainty and concerns raised by its biosafety and environmental impacts. The rise of modern biotechnologies and life science bring many surprises, change the paradigms of the society and revolutionize our daily lives. Against the many exciting successful examples of biotechnology, it is impor-

\footnotetext{
* Author for correspondence. Tel:8862-23630231 ext. 3813; Fax:8862-23627044; E-mail:tmpan@ccms.ntu.edu.tw
}

tant that all technologies, bio and non-bio, are to serve the ultimate objective of improving the overall welfare of human beings and the nature. Agricultural biotechnology is no exception. It is the foundation of people's livelihood. Application of agro-biotechnology should focus on providing stable food supply and improving food quality.

By genetically improving drought resistance of crops, people will have better access to food. Another example is that the rapid expansion of the production of "golden rice" improves the nutrition of the poor in Africa. On the other hand, many people believe that biotechnology will bring irreversible damages to the world. This voice of opposition comes mostly from environmental, consumer and religious groups. To this group of people, the risk poses by biotechnology outweighs the benefit. Insufficient information and lack of confidence in the public sector's ability to properly regulate biotechnology further complicates the situation ${ }^{(6)}$.

\section{CURRENT STATUS OF GMO}

\section{Application of Biotechnology to Agriculture}

People around the world have developed and extensively used many biotechnologies. Some biotechnologies have been documented for millennia, including manipulating microorganisms during fermentation to make bread, beer, wine, beverage, soy sauce, cheese and many other food products. Accumulated knowledge about DNA stimulated the rapid development of genetic engineering technology. 
With genetic engineering, scientists are now able to manipulate various traits of different species. New technologies such as tissue culture, cell culture and embryo transfer, as well as various techniques of molecular manipulation in agriculture, have emerged. Transgenesis technologies have been widely used in crop breeding and propagation of plants. Furthermore, modern biotechnology now can be applied to cure diseases, prolong lives and even clone living organisms. The controversy surrounding agricultural biotechnology differs from application to application. With the wide application of genetic engineering technologies in manipulating genetic traits, novel species known as genetically modified organisms (GMO) and living modified organisms (LMO) begin to emerge. Agricultural application of biotechnology also attracts attention of various stakeholders. Nevertheless, genetically modified (GM) crops in particular are increasing in production at a very fast speed.

\section{Current Status of Genetically Modified Organisms}

There were virtually no GM crops on the field before the 1990s. The first GM crop-tomato was sold in the market in 1994. Nowadays, the estimated global area of transgenic or GM crops for 2001 is already 52.6 million hectares in 13 countries $^{(7)}$. The global area of biotech crops 1995-2000, by crop and by countries are shown in Figure 1 and 2.The global area of biotech crops are increased by $19 \%$ (8.4 million hectares) from 2000 to 2001. Between 1996 and 2001, the total area of GM crops grew about 30 times. Production of GM crops is currently concentrated in just a few countries while more countries are experimenting new traits. In 2001, 99\% of GM crops are produced in four countries: US $68 \%$, Argentina $11.8 \%$, Canada $6 \%$ and China 3\%. Crop-wise, GM soybean made up $63 \%$ of global GM planting area and GM corn accounts for $19 \%$, followed by GM cotton (13\%) and GM canola (5\%). In terms of the global planting area, GM soybean and cotton accounted for $46 \%$ and $20 \%$, respectively ${ }^{(7)}$. The same report also indicated that the two

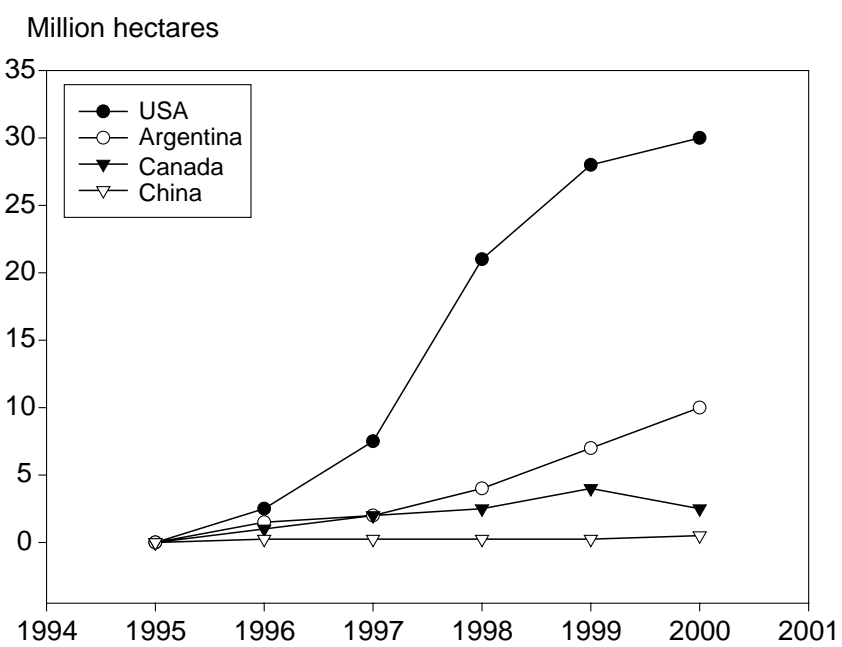

Figure 1. Global area of biotech crops 1995-2000 by country Source: Clive James, ISAAA

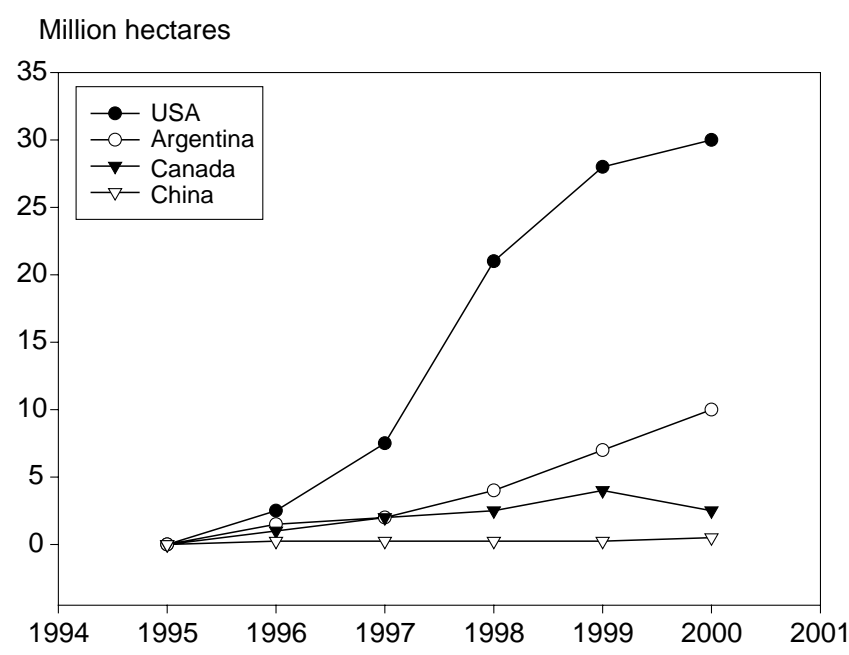

Figure 2. Global area of biotech crops 1995-2000 by crop Source: Clive James, ISAAA

major GMO traits in 2001 were herbicide tolerant crops, accounted for $77 \%$ of all GM crops, while Bt maize accounted for $11 \%$.

Furthermore, biotechnology is one of the fastest-growing sectors of the economy in recent years. In 2000, 101 private biotech companies (agro and non-agro) went public on stock exchanges, raising a total capital of about US\$ 20 billion $^{(8)}$. In terms of technology ownership, $71 \%$ of all agrobiotechnology patents are owned by the top five companies, namely Pharmacia (21\%, 287 patents), DuPont (20\%, 279 patents), Syngenta (13\%, 173 patents), Dow (11\%, 157 patents), and Aventis (6\%, 77 patents).

\section{The Benefit of Biotechnology in Agriculture}

In order to present a balanced view of biotechnological role on agriculture, biosafety and risks will be examined first. The benefits of biotechnology are long recognized by many, including the leader of the Green Revolution and 1970 Nobel Peace Prize laureate Norman Borlaug. Perhaps one of the most often cited benefit of biotechnology in agriculture is to increase food productivity and hence reduce hunger. Other benefits include improving nutrition intake, conserving the environment by reducing pesticide and herbicide uses, and improving food quality $(9,10,11,12)$. Two major events further mark the beginning of the global biotechnology era are the conclusion of the Cartagena Protocol on Biosafety in 2000 and the recent World Food Summit held in Rome in June 2002(13). The Cartagena Protocol on Biosafety represents the first major consensus through which all issues of biotechnology are no longer philosophical or ideological, but deemed to be of technical nature. This is a great accomplishment since it transforms conflicting arguments into workable topics. Endorsement of the 2002 World Food Summit further confirms the acceptance of biotechnology application in the development of agriculture, particularly in securing food security for the interna- 
tional community, particularly, the developing countries that may be the major users and beneficiaries of biotechnology in the future.

\section{Biosafety and Risks of GM Products}

Against this background, there are several issues surrounding the biosafety of biotechnology. The core is risk and uncertainty. The major difference between the "sciencebased approach" of exporting countries and the "precautionary principle" of importing countries comes down to different views of how risk and uncertainty of GM products should be managed. Environmental and ethical concerns arise from the perceived risk of GM products for the future generations. Consumers demand their right to know what is in the food they buy by labeling GM products to minimize the risk of consuming these products. Therefore, it may be fair to say that the key to the solution of current concern and debate over biotechnology is risk management.

The general public concerns about risk assessment of GM products because many GM products are used for food. Therefore, biosafety related issues of GM products must be properly addressed to make sure that there is no potential harzard to human beings and the environment before they are introduced to the market. Approach to manage the risk assessment associated with biotechnology and GM products of countries around the world have been debated in various occasions. However, there seems to be a potential balance point at which there is an emerging consensus over a set of policy tools such as labeling, standards and assessment procedures. In 2001, a conference in Bangkok co-hosted by OECD, FAO, WHO, UNEP, CBD and the British and Thai governments discussed several related issues including anticipation of unintended effects, assessment methodology of risk and benefit, validation of information, public sector support for research, and coordinated multilateral process ${ }^{(14)}$. With continuous dialogues and concerted efforts, the public sector plays an increasingly important role in the development of biotechnology.

The environmental concerns derived from GM products are perhaps most difficult to address since the effects on components of the ecosystem are not easily observable in the short-term. Opponents of agro-biotechnology argue that
GMO species may crossbreed with non-GMO species and become the dominant species thus change the ecosystem. There are also concerns about the possible detrimental effects on other species and soil flora and fauna, loss of biodiversity, development of resistance mechanism, and interruption of the ecosystem. In this regard, Serageldin and Persley ${ }^{(15)}$ propose that the following areas must receive continuous emphasis: efficient regulations, clear guidelines for field tests, commercialization of LMOs, systematic capacity building, international support of an early warning system, and additional scientific research on the impact to the environment and risk to biodiversity. The environmental impacts of GM products have been discussed in many occasions. All stakeholders seem to agree that the development and promotion of agro-biotechnology and GM products must take the environmental factor into full consideration during risk assessment to avoid unpredictable environmental hazards.

In ROC, the Genetically Modified Food Advisory Committee (GMFAC) was commissioned by DOH in 2001 with the responsibility to conduct safety evaluation of GM food according to the Guidance of Safety Assessment for Genetically Modified Food ${ }^{(16)}$ for science-based risk assessment. The GMFAC consists experts from universities and research institutes in variety of disciplines, including molecular biology, botany, agronomics, nutrition, toxicology, immunology and food science. The members are recruited through public recommendations from professional sources.

Eight applications, including one GM soybean and seven GM corns, have been submitted to DOH by April 30, 2002. Up to the end of August, GMFAC approved one Roundup Ready soybean (DOH permit issued in July) and three GM corns, MON810, GA21and T25 (DOH permits to be issued when National Laboratories of Foods and Drugs completes the testing). (See Table 1) ${ }^{(17)}$.

\section{The Necessity of the Detection of GMO}

Food safety is concerned with consumers' right to know what is in the products they buy. Without transparent information flow of GM products, informed choice can not be sustained. Lack of information also negatively impacts the development of biotechnology. According to

Table 1. Current applications and approvals of GMO in Taiwan

\begin{tabular}{lllccl}
\hline Product & \multicolumn{1}{c}{ Name } & \multicolumn{1}{c}{ Event } & Applicant & $\begin{array}{c}\text { Date of DOH } \\
\text { Approval }\end{array}$ & Note \\
\hline Soybean & $\begin{array}{l}\text { Glyphosate tolerant Roundup } \\
\text { Ready }{ }^{\circledR} \text { Soybean }\end{array}$ & 40-3-2 (RRS) & Monsanto & $07 / 22 / 2002$ & GMFAC approved, 06/03/2002 \\
Corn & Insect-resistant YieldGard ${ }^{\circledR}$ corn & MON810 & Monsanto & -- & GMFAC approved, 07/30/2002 \\
Corn & Glyphosate tolerant Roundup Ready ${ }^{\circledR}$ corn & GA21 & Monsanto & -- & GMFAC approved, 06/03/2002 \\
Corn & Glyphosate tolerant Roundup Ready ${ }^{\circledR}$ corn & NK603 & Monsanto & -- & Under GMFAC evaluation \\
Corn & Insect-resistant / Glufosinate tolerant corn & Bt11 & Syngenta & -- & Under GMFAC evaluation \\
Corn & Insect-resistant Bt corn & Event176 & Syngenta & -- & Under GMFAC evaluation \\
Corn & Glufosinate tolerant corn & T25 & Aventis CropScience & -- & GMFAC approved, 07/30/2002 \\
Corn & Insect-resistant / Glufosinate tolerant corn & TC1507 & DuPont & -- & Under GMFAC evaluation \\
\hline
\end{tabular}

GMFAC: Genetically Modified Food Advisory Committee. 
Dickson $^{(18)}$, a survey in the U.S. showes that almost $2 / 3$ of the respondents are "very concerned' or "somewhat concerned" about the food safety problem of GM products. Other studies in Japan and Europe show a decline of confidence in biotechnology product ${ }^{(18)}$. Consumers are eager to know what long-term and short-term effects GM products may have on human beings and the environment. Food derived from biotechnology will face constant challenges from consumers around the world until information and evidence of the issues raised can be provided.

As the result of public relation programs carried out by major grain biotech producers in North America in the early 1980s to the general public in North America has shown less resistance to the introduction of GM foods ${ }^{(19)}$. However, these modified foods have not gained worldwide acceptance because of consumer suspicion resulting from earlier food and environmental concerns, lack of transparent regulatory and mistrust in government bureaucracies. These factors fueled debates about the environmental and public health safety issues of introduced genes (e.g. potential gene flow to other organisms, the destruction of agricultural diversity, allerginicity, antibiotic resistance and gastrointestinal problems $\left.{ }^{(19,20)}\right)$.

Some of the major regulatory and scientific agencies in the world believe that GM crops pose no greater threat to human health than those posed by traditional crop breeding approaches ${ }^{(21,22)}$. Nevertheless, some countries introduced mandatory-labeling legislation of GM foods to give their consumers a choice in selecting the foods they feel comfortable with ${ }^{(23)}$. An agreement, the "Cartagena Biosafety Protocol', governs the trade and transfer of GMOs across international borders and allows governments to prohibit importation of GM food when there is concern over its safety ${ }^{(24)}$. Universal legislation makes it imperative for governments, the food industry, testing laboratories and crop producers to develop ways to accurately quantitate GMOs in crops, foods and food ingredients to assure compliance with threshold levels of GM products.

\section{GMO TESTING}

\section{Types of GMO Testing}

GM products contain an additional trait encoded by introduced gene(s), which generally produce additional protein(s) that confers the trait of interest. Raw materials (e.g. grains) and processed products (e.g. foods) derived from GM crops might thus be identified by testing for the presence of introduced DNA, or by detecting expressed novel proteins encoded by the genetic material. Both qualitative (i.e. those that give a yes/no answer) and quantitative methods are available ${ }^{(25)}$.

\section{Reference Materials for GMO Testing}

Appropriate reference materials for positive and negative controls provide the basis for the validation of analytical procedures and the performance assessment of methods and laboratories. Reference material should be independent of the analytical methods and should be focused on raw material or base ingredients rather than on finished foods. Each GMO requires specific reference material. Grains, altered DNA or expressed proteins have all been used as reference material. If grains are used, they should mimic real-life test material ${ }^{(23)}$. In a few cases, both genomic and plasmid DNA have been used as reference material. The former is more realistic in terms of matrix effect, whereas the latter is easier to prepare in large quantities and may provide greater consistency. In contrast to protein detection methods, in which a single standard can be settled relatively easily, DNA-based methods are better served through combinations of several positive controls. The availability of reference materials is currently limited due to concerns over intellectual property rights and costs ${ }^{(26)}$. The Institute of Reference Materials and Measurements at the Joint Research Center in Geel, Belgium, offers a limited number of reference materials [through Fluka (Buchs, Switzerland)] for modified soya, corn and maximizer maize (MM).

\section{Sampling of GM Products for Testing}

Both sample size and sampling procedures are important issues for testing GMOs in raw materials and food ingredients if one is to avoid problems of nonhomogeneity. The sampling plan should be performed in a manner that ensures a statistically representative sample, and the sample size must be sufficient to allow adequate sensitivity, because the statistical significance achievable with a small sample size is weak ${ }^{(27)}$. The raw sample (or seed) is ground into fine powder and mixed thoroughly, followed by extraction of either protein or DNA for subsequent testing. Although no sampling protocols have been developed that specifically address the challenges associated with detecting biotechnologically derived grains, there are adequate government plans, such as those published by Grain Inspection, Packers and Stockyards Administration (GIPSA) of the US Dept of Agriculture $^{(28)}$ and the Ministry of Health, Labour and Welfare, Japan ${ }^{(29)}$. The optimum sampling strategy is a balance between sensitivity, cost and confidence. It would, however, be desirable if sampling plans were coordinated on a worldwide basis (e.g. through the Codex Alimentarius Commission of the UN) to ensure adequacy of testing ${ }^{(30)}$.

The United States Department of Agriculture (USDA), Grain Inspection, Packers and Stockyards Administration (GIPSA, Washington, D.C.) have recently established sampling guidelines for diagnostic testing for GM grains ${ }^{(31)}$. For example, on the basis of the formula (designed for a single-step sampling procedure and qualitative analytical testing):

$n=\log (1-(G / 100) / \log (1-(P / 100))$

where $n$ is the sample size (number of kernels), $G$ is the probability of rejecting a lot concentration, and $P$ is percent concentration in the lot, the sample size should amount to 299 kernels or beans in order to obtain a $95 \%$ probability of 
rejecting a lot with $1 \%$ concentration of GMO, i.e. a "buyer's risk" of 5\% to accept a lot with more than $1 \%$ GMO content ${ }^{(31)}$. If the threshold limit was set at $0.5 \%$ GMO at a $95 \%$ probability of rejection, the size of the field sample would need to be increased up to 598 kernels. However, at a sample size of 299 kernels the "seller's risk" of having a lot rejected, which contains only $0.5 \%$ GMO, is still about $78 \%$. Therefore, in order to provide means of controlling marketing risks for both buyer and seller, multiple sampling plans for qualitative analytical testing have been developed ${ }^{(31,32)}$. A multiple sampling plan is defined by the number of samples needed and tested, by the maximum number of positive results allowed for the lot to be acceptable, and by the number of kernels in each sample. Buyer and seller have to agree on these three values, and thereby determine the marketing risk both of them are willing to take $\mathrm{e}^{(31)}$.

\section{DNA-BASED TESTING METHODS}

Irrespective of the variety of methods used for DNA analysis, only PCR in its different formats has been widely applied in GMO detection/analysis and generally accepted for regulatory compliance purposes.

Detection methods based on DNA rely on the complementarity of two strands of DNA double helix that hybridize in a sequence-specific manner. The DNA of GMO consists of several elements that govern its functioning. The elements are promoter sequence, structural gene and stop sequence for the gene. Although several techniques are available, only Southern blot and particularly PCR analy$\operatorname{ses}^{(33,34)}$ are commonly used. Microarray technology is currently under development ${ }^{(35)}$.

\section{DNA Isolation Methods}

The efficiency of the PCR, as with any other DNA assay, depends on the DNA quality and purity. DNA quality is determined by its fragment length and its degree of damage due to the exposure to heat, low $\mathrm{pH}$ and/or nucleases that cause hydrolysis, depurination and/or enzymatic degradation. Therefore, DNA quality varies according to the material under examination, the degree of processing the sample has been subjected to, and the DNA extraction method applied. It is important that DNA isolated from processed foods and certain agricultural materials, such as cured tobacco leaf, is of low quality with short target sequences, e.g. 100 to $400 \mathrm{bp}$ for soybean protein preparations and processed tomato products ${ }^{(36)}$. Thus, an appropriate choice of primers to obtain short amplicons should be made.

The purity of DNA can be severely affected by various contaminants in food matrices ${ }^{(37)}$. Contaminants may be substances originating from the material under examination (polysaccharides, lipids and polyphenols) or chemicals used during the DNA extraction procedure, e.g. as reported for cetyltrimethylammonium bromide (CTAB), or hexade- cyltrimethyl ammonium bromide, ROSE and the alkali method $^{(38)}$. For example, Taq polymerase, the key enzyme used in the PCR reaction, is inhibited by polysaccharides, ethylenediaminetetraacetic acid (EDTA), phenol, and sodium dodecylsulphate (SDS), etc.

A vast range of methods is available for DNA isolation and many of them have been evaluated for their applicability to GMO detection in plant material and plant derived foods. Currently, three different approaches to DNA isolation from plant material and plant-derived products are favored for GMO detection: the CTAB-method, DNA binding silica columns (various commercially available kits), and a combination of these two. Although the use of these methods often results in rather low yields, the quality and purity of the DNA is satisfactory in comparison to that obtained with other methods, e.g. alkali, Chelex100, or ROSE ${ }^{(38)}$ which yield larger amounts of low quality DNA.

\section{Southern Blot}

This method involves fixation of isolated sample DNA onto nitrocellulose or nylon membranes, the probing with double-stranded (ds)-labeled nucleic acid probes specific to the GMO, and the detection of hybridization radiographically, fluoremetrically or by chemiluminescence. Earlier probes were labeled with ${ }^{32} \mathrm{P}$. However, non-radioactive fluoresceinlabeled $\mathrm{DNA}^{(39)}$, digoxigenin-, or biotin-labeled DNA probes, with sensitivity equal to ${ }^{32} \mathrm{P}$ probes, are recently used, obviating the need for radioactivity in the testing laboratory. These non-radioactive probes reduced detection to less than $1 \mathrm{hr}$, as opposed to $24 \mathrm{hrs}$ labeling required by ${ }^{32} \mathrm{P}$. However, because only one probe is used and no amplification is carried out, this method is considered less sensitive than PCR, which employs DNA of two primers.

An alternative Southern blot technology with near infrared (NIR) fluorescent dyes (emitting at 700 and 800 $\mathrm{nm})$ coupled to a carbodiimide-reactive group and attached directly to DNA in a 5 min reaction has been attempted recently. The signals for both dyes are detected simultaneously by two detectors of an infrared imager, something not yet possible with conventional radioactive or chemiluminescent detection techniques ${ }^{(40)}$.

\section{Qualitative PCR}

PCR also exploits the specificity of DNA polymerase to allow the selective amplification of specific DNA segments occurring at low frequency in a complex mixture of other DNA sequences ${ }^{(34)}$. In a standard PCR test, two pairs of primers are used. These primers are designed to hybridize on opposite strands of the sequence of interest, and amplify the sequence between the primers millions of times through a series of repetitive cycles. Amplified pieces can be subjected to agarose gel electrophoresis to separate amplified DNA according to size, although other separation methods, such as high performance liquid chromatography (HPLC) and capillary electrophoresis (CE), have been 
used $^{(34,41)}$. Several food ingredients (e.g. soy, wheat, canola, potatoes, rice, maize, celery and tomatoes) have been analyzed using PCR. A crucial rate-limiting step is DNA extraction and purification. Currently, several methods of extraction are available, but only two are widely used: the CTAB method, based on incubating food sample in the presence of the detergent cetyltrimethylammonium bromide $^{(42)}$, and the Wizard method, employing DNA-binding silica resins (Promega Corp., Madison, WI) ${ }^{(43)}$. Both costeffective methods produce satisfactory DNA isolation without unacceptable DNA degradation. Factors such as excessive heat, nuclease activity and low $\mathrm{pH}$ (quite common in food processing) contribute to DNA degradation. This is most likely for products with long shelf lives, such as prepared meatballs in tomato sauce and beefburgers. Compounds present in foods (e.g. proteins, fats, polysaccharides, polyphenols, cocoa extracts and caramelized sugar) can inhibit DNA polymerase ${ }^{(44)}$, and data suggest that the critical minimum average DNA size for successful PCR analysis is about $400 \mathrm{bp}^{(45)}$.

Most currently available GMOs contain any one of three genetic elements: the cauliflower mosaic virus (CaMV) 35S promoter, the nopalin synthase (NOS) terminator, and the kanamycin-resistance marker gene (nptII) and others. These elements also occur naturally in some plants and soil microorganisms, and can thus be detected using PCR, giving false-positive results. If the PCR assay gives a positive result, product-specific PCR methods that have been developed for a range of different GM foods can be carried out. These methods exploit a set of primer pairs that span the boundary of two adjacent genetic elements (e.g. promoters, target genes and terminators), or that are specific for detection of the altered target gene sequence. Detection limits are in the range of $20 \mathrm{pg}$ to $10 \mathrm{ng}$ of target DNA and $0.0001 \%$ to $1 \%$ of the mass fraction of GMOs ${ }^{(23)}$.

Different methods can be used to confirm the PCR results. The first one is specific cleavage of the amplified product by restriction endonuclease digestion ${ }^{(46)}$. The secondary method is the hybridization with a DNA probe specific for the target sequence ${ }^{(47)}$. The third one is the direct sequencing of the PCR product ${ }^{(33)}$. The last one is nested $\mathrm{PCR}^{(48)}$, in which two sets of primer pairs bind specifically to the amplified target sequence. The examination results of the sensitivity of the nested PCR is shown in Figure 3.

Recently, GeneScan Europe has introduced a test kit for the detection of GMOs in food products, which allows a multiplex PCR for the specific detection of DNA sequences from plant species and GM traits ${ }^{(49)}$. The procedure starts with the isolation and purification of DNA from the sample. Then, specific DNA sequences from both plant species and GM traits are amplified by two separate multiplex PCR reactions, products of both reactions mixed, and singlestranded (ss) DNA is created by digestion with an exonuclease. After mixing with hybridization buffer, the sample is spread on the chip. Amplified sequences that will hybridize with cDNA probes covalently bound in the chip are stained with the fluorescent dye Cy5 and analyzed by a biochip reader (e.g. Biodetect $654^{\mathrm{TM}}$ ). The detection limit for the GMO Chip Kit is in the range of 250 copies of each of the target DNA sequences in the PCR.

\section{Quantitative End-point PCR}

A crucial aspect of analysis of GMOs in food is quantitation, because maximum limits of GMOs in foods are the basis for labeling in many countries, such as $\mathrm{EU}^{(50,51)}$, Japan, Korea and Taiwan ${ }^{(52)}$. Therefore, more quantitative PCR approaches are needed. PCR is quantitative if an internal DNA standard is co-amplified with target $\mathrm{DNA}^{(53)}$. In systems such as the quantitative competitive (QC)-PCR method, the presence of PCR inhibitors will be noticed immediately because the amplification of both internal standard and target DNA will be simultaneously affected ${ }^{(54)}$. QC-PCR consists of four steps: (1) co-amplification of standard- and target-DNA in the same reaction tube; (2) separation of the products by an appropriate method, such as agarose gel electrophoresis and staining the gel by ethidium bromide; (3) analysis of the gel densitometrically; and (4) estimation of the relative amounts of target and standard DNA by regression analysis. At the equivalence point, the starting concentration of internal standard and target are equal. In the QC-PCR, the competition between the amplification of internal standard DNA and target DNA generally leads to loss of detection sensitivity.

PCR-ELISA uses the strategy of the second group and can be quantitative when the PCR is stopped before a significant decrease in amplification efficiency occurs. ELISA has been used to quantify the relatively low amounts of PCR products $^{(55,56)}$. Despite the fact that relative quantification using PCR-ELISA has been applied in different fields ${ }^{(57)}$ and that a GMO detection kit using PCR-ELISA has been commercialized (D-Genos, Angers, France), this technique has not been widely adopted for accurate GMO quantification purposes.

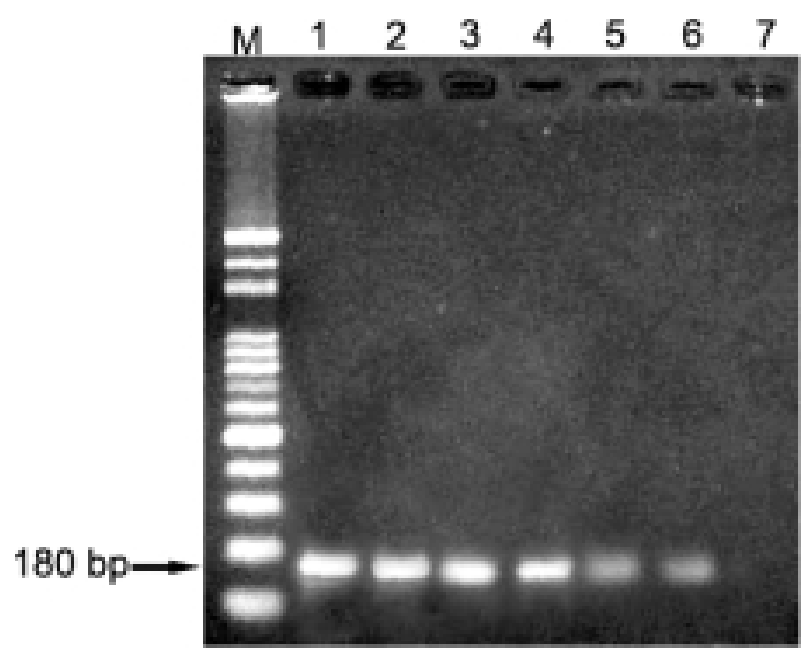

Figure 3. Examination of the sensitivity of the nested PCR The nested PCR is used to examine $1 \mathrm{ng}$ (lanes 1 and 2), $0.1 \mathrm{ng}$ (lanes 3 and 4), and $0.01 \mathrm{ng}$ (lanes 5 and 6) of Roundup Ready soybean. Lane 7 is the negative control, which does not contain DNA template. 


\section{Quantitative Real-time PCR}

To circumvent some of the problems of conventional quantitative end-point PCR, a real-time Q-PCR was introduced $^{(58)}$. In theory, production of PCR products should proceed exponentially. However, in practice it reaches a plateau between 30 and 40 cycles because certain reaction components become limited ${ }^{(41)}$. In conventional PCR, products of the reaction are measured at a single point in the reaction profile. Plotting the concentration of products present at this point as a function of the initial amount of DNA present in each of those reactions shows that proportionality between DNA concentration (dynamic range) and PCR products occurs over a limited range of DNA concentrations, leading to loss of precision in quantitation. However, it has been shown empirically that the concentration of DNA in real-time PCR reaction is proportional to PCR cycle number during the exponential phase of $\mathrm{PCR}^{(59)}$. Therefore, if the number of cycles it takes for a sample to reach the same point in its exponential growth curve is known, its precise initial DNA (and then GMO) content can be determined. Real-time PCR also allows for detection of low copy DNA number ${ }^{(60)}$. Several commercially available real-time PCR thermal cyclers automate the analytical procedure and allow cycle-by-cycle monitoring of reaction kinetics, permitting calculation of the target sequence concentration. Several formats are used to estimate the amount of PCR product: (1) the ds-DNA-binding dye SYBR Green I; (2) hybridization probes or fluorescence resonance energy transfer (FRET) probes; (3) hydrolysis probes (TaqMan ${ }^{\circledR}$ technology); and (4) molecular beacons ${ }^{(60)}$. These systems also permit differentiation between specific and nonspecific PCR products (such as primer-dimer) by the probe hybridization or by melt curve analysis of PCR products, because nonspecific products tend to melt at a much lower temperature than do the longer specific products ${ }^{(60)}$. A total of 179 food products containing GM RRS (e.g. baby food and diet products, soy drinks and desserts, tofu and tofu products, cereals, noodles, fats, oils and condiments) were analyzed by TaqMan ${ }^{\circledR}$. The method proved to be sensitive. However, amplifiable soy DNA could not be detected in fats, oils and condiments. The genetic modification of RRS was detected in 34 samples, eight of which contained more than $1 \% \operatorname{RRS}^{(61)}$.

ABI Prism 7700, employing TaqMan ${ }^{\circledR}$ in a relative quantitative PCR, detected 2 pg of MM and RRS per gram of starting sample in $3 \mathrm{hr}$ after DNA extraction ${ }^{(62)}$. The result of PCR product detection in real time using the GeneAmp ${ }^{\circledR} 5700$ Sequence system are shown in Figure 4. PCR was carried out in a Perkin-Elmer AB5700 SDS (Applied Biosystem, Foster, CA). The fluorescent signal of ds-DNA- binding dye, SYBR Green I will increase when the PCR products increase in PCR. On the amplification curve plotting the increasing amount of luminescent signals $(\Delta R n)$, select the $\Delta \mathrm{Rn}$ part where luminescent signals from both of the standard solution for the standard curve and DNA sample solution amplify exponentially, and draw a threshold line. Use the point, where the threshold line and lumines- cent signal of the standard solution for standard curve cross, as the threshold cycle $(\mathrm{Ct})$. We can draw a standard curve (Fig. 4.) and calculate the DNA concentration of unknown sample by its $\mathrm{Ct}$ in real time PCR. The system permit differentiation between the specific and non-specific PCR products (such as primer-dimer) by the melting curve analysis of PCR products, because non-specific products tend to melt at a much lower temperature than do the longer specific products.

Figure 5 shows the amplification of the epsps gene in seven-fold dilutions of plasmid DNA contained the epsps gene using the ABI Prism ${ }^{\circledR} 7700$ Sequence Detection system. In Figure 5, using the hydrolysis probe (TaqMan ${ }^{\circledR}$

(A)

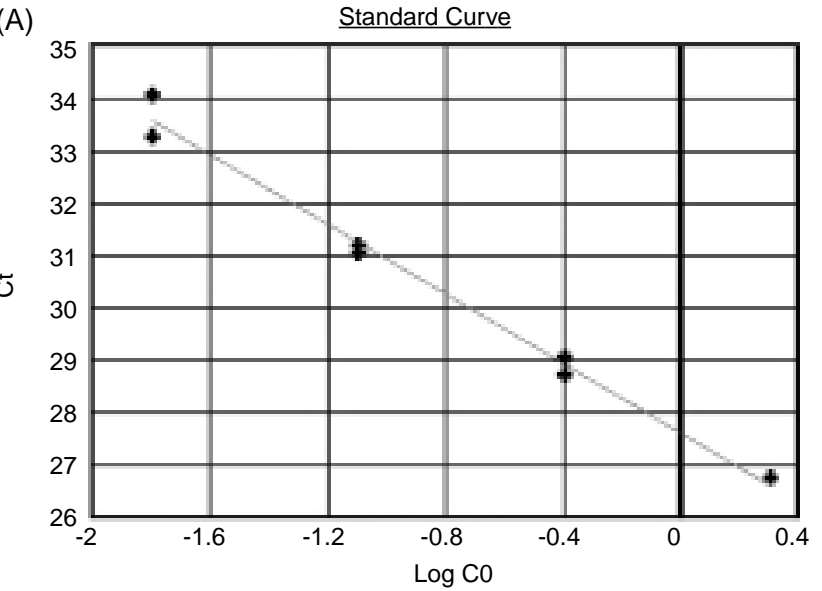

(B)

Rn vs Cycles

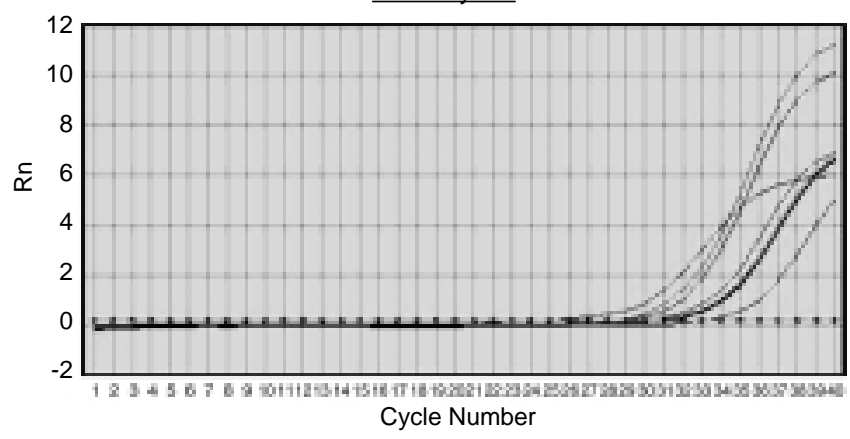

(C)

Dissociation Curve

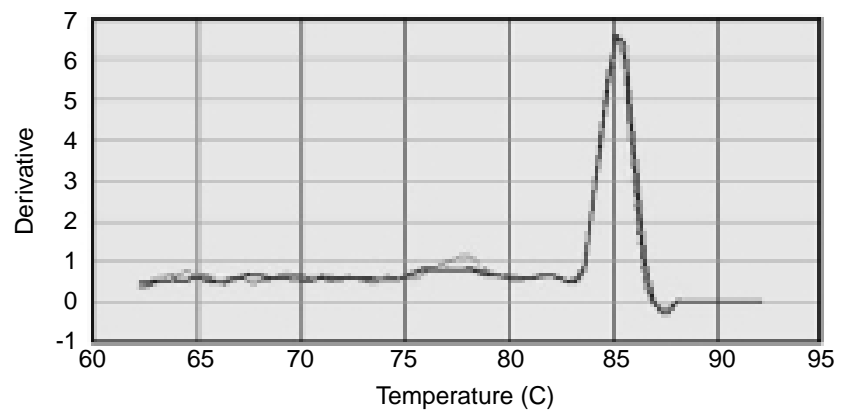

Figure 4. PCR product detection in real time. (A) Standard curve showing $\mathrm{Ct}$ values plotted versus the log of the initial concentration of $35 \mathrm{~S}$ gene. (B) Amplification of the $35 \mathrm{~S}$ promoter in five-fold dilutions of genomic DNA of $2 \%$ RRS using the GeneAmp ${ }^{\circledR} 5700$ Sequence system. (C) Dissociation curve of PCR products. 
technology) to estimate the amount of DNA, the probe complementary to part of the target sequences, epsps gene, are labeled with the dyes FAM and TAMRA as reporter and quencher. The fluorescent signal is generated during the extension phase of DNA amplification as the exonuclease activity of Taq polymerase separates the fluorophore from the quencher molecules. The increasing amount of fluorescent signal is proportional to the increasing amount of amplification product generated in each amplification cycle.

Several formats are used to estimate the amount of DNA of PCR products: (1) the ds-strand DNA-binding dye SYBR Green I; (2) hybridization probes or fluorescent energy transfer (FRET); (3) hydrolysis probe (TaqMan ${ }^{\circledR}$ technology)

An increasing number of food control laboratories are adopting PCR as the technology of choice for GMO detection. The first official methods that have been validated in ring trials are published in the Swiss Food Manual and the German official collection of test methods in accordance with Article 35 of the German Food Act ${ }^{(59,63,64,65)}$. However, international standardization and validation of GMO analysis methods by harmonized and accepted protocols is still in its early phases. Standardization bodies, such as CEN and the French Standardization Association (AFNOR Paris, France), have undertaken activities in this area and established preliminary guidelines for sampling strategies and GMO detection methods, respectively ${ }^{(66)}$.

The objective of validation of an analytical PCR method is to demonstrate that the successive procedures of sample extraction, preparation and analysis will yield accurate, precise and reproducible results for a given analyte in a specified matrix. The process of validation allows the independent use of methods and results, which are comparable among each other. Depending upon the intended purpose of the analysis, i.e. qualitative or quantitative analysis, different validation parameters have to be evaluated. For the validation of a qualitative analytical test system specificity, sensitivity, accuracy and robustness have to be established ${ }^{(67)}$.

\section{PROTEIN-BASED TESTING METHODS}

Immunoassay is ideal for the detection of many types of proteins in complex matrices when the target analyte is known ${ }^{(68)}$. Both monoclonal (highly specific) and polyclonal (often more sensitive) antibodies can be used depending on the amounts needed, the specificity of the detection system, the particular application, and time allotted for testing and cost. On the basis of typical concentrations of transgenic material in plant tissue (more than $10 \mu \mathrm{g}$ per tissue), the detection limits of protein immunoassays can predict the presence of modified proteins in the range of $1 \%$ GMOs $^{(69)}$. Immunoassays with antibodies attached to a solid phase have been used in two formats. The first format is a competitive assay in which the detector and analyte compete to bind with capture antibodies. The second format is a two-site (double antibody sandwich) assay in which the analyte is sandwiched between the capture antibody and the detector

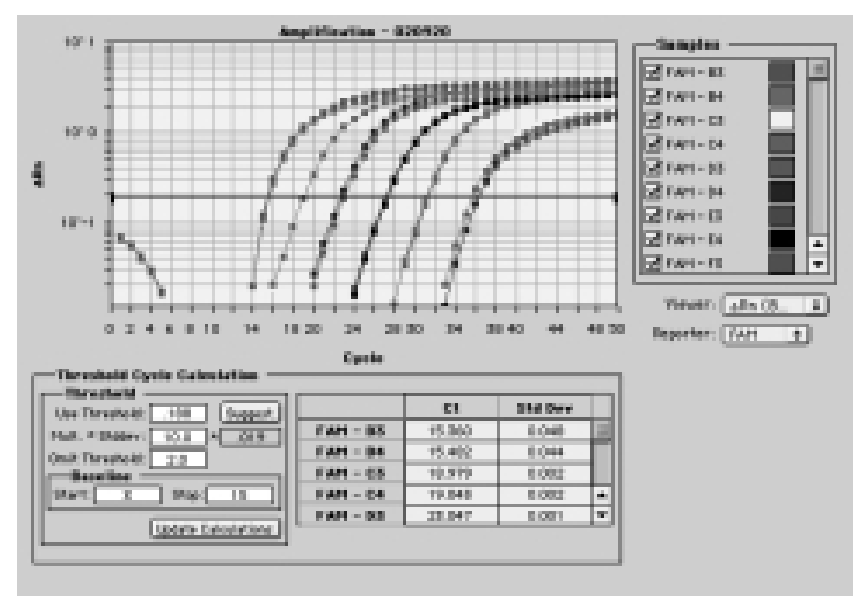

Figure 5. Amplification of the epsps gene in seven-fold dilutions of plasmid DNA contained the epsps gene using the ABI Prism ${ }^{\circledR} 7700$ Sequence Detection system.

antibody ${ }^{(70)}$. Both western blot and enzyme-linked immunosorbant assay (ELISA) techniques have been used for the analysis of protein products of Monsanto's transgenic Roundup Ready soybean (RRS) ${ }^{(71)}$.

\section{ELISA}

There are two formats in ELISA: the microwell plate (or strip) format and coated tube format. The antibody-coated microwells with removable strips of 8-12 wells are quantitative and highly sensitive. They are ideal for quantitative high-volume laboratory analysis, provided the protein is not denatured. The average run time for a plate assay is about $90 \mathrm{~min}$, and an optical plate reader determines concentration levels in the samples. Detection limits for CP4 EPSPS soybean protein is $0.25 \%$ for seeds and $1.4 \%$ for toasted meal $^{(23)}$. The second format is suitable for field-testing, with typical run times ranging from 15 to 30 mins. Tubes can be read either visually or by an optical tube reader and results are qualitative. Because there is no quantitative internal standard within the assay, no extra information can be obtained concerning the presence of GMOs at the ingredient level in food ${ }^{(72)}$. The principle of lateral flow strip assay format (the secondary format) is shown in Figure 6. The side view illustrates principles of the immunological test and relative location of control and test lines on a nitrocellulose strip. The vertical view of test strips dipped in an eppendorf contains genetically modified material and shows both negative and positive test results

\section{Western Blot}

The western blot is a method that provides qualitative determination whether the target protein level is below or above a predetermined threshold ${ }^{(73)}$. It is particularly useful for the analysis of insoluble protein ${ }^{(74)}$. This method is considered more suitable for research applications than for routine testing. The samples to be assayed are solubilized with 
(A)

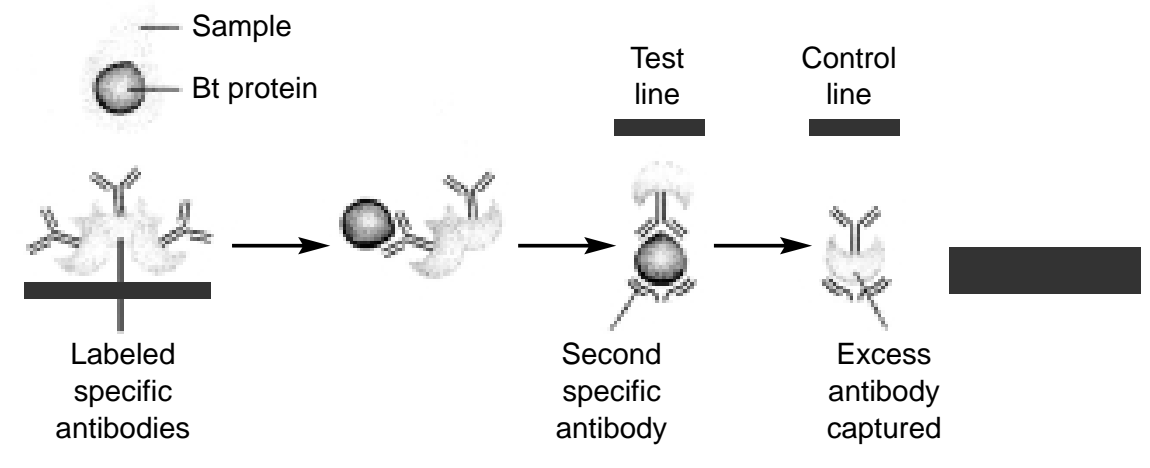

(B)

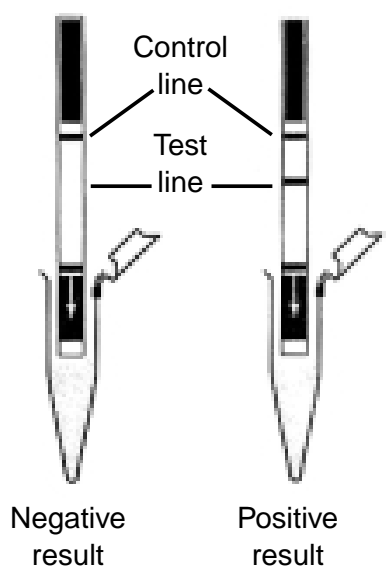

Figure 6. Lateral flow strip assay format (A) Side view illustrating principles of the immunological test and relative location of control and test lines on a nitrocellulose strip. (B) Vertical view of test strips dipped in an eppendorf containing genetically modified material, and showing both negative and positive test results. Abbreviation: Bt, (Source: Ahmed, F. E. 2002)

detergents and reducing agents, and separated by sodium dodecyl sulfate (SDS)-polyacrylamide gel electrophoresis. The components are transferred to nitrocellulose membrane, and binding immunoglobulin sites on the membrane are blocked by dried nonfat milk. The specific sites are then probed with antibodies. Then the bounded antibody is stained with Ponceau, silver nitrate or Coomassie, or a secondary immunological reagent, such as protein A coupled to horseradish-peroxidase (HRP) or alkaline phosphatase ${ }^{(33)}$. The detection limits of western blots vary between $0.25 \%$ for seeds and $1 \%$ for toasted meal ${ }^{(23)}$.

\section{Lateral Flow Strip}

Lateral flow strip technology is a variation on ELISA, using strips rather than microtiter wells. Immobilized double antibodies, specific for the expressed protein, are coupled to a color reactant and incorporated into a nitrocellulose strip. When the strip is placed in a plastic eppendrof vial containing an extract from plant tissue harboring a transgenic protein, it leads to an antibody sandwich with some of the antibody that is coupled to the color reagent. This colored sandwich flows to the other end of the strip through a porous membrane that contains two captured zones, one specific for the transgenic protein sandwich and another specific for untreated antibodies coupled to the color reagent. Presence of only one (control) line on the membrane indicates a negative sample, and presence of two lines indicates a positive result. The lateral flow format gives results in 5 to 10 mins. It is economical, more amenable to point-of-sale application, and suitable as an initial screening method early in the food chain. These strips have been developed commercially to detect endotoxins expressed by Bacillus thuringiensis that protect against insects, as in $\operatorname{CryI}(\mathrm{Ab})$ (in corn plants, seeds and grain) and CP4 EPSPS protein (in soybean, canola, cotton and sugar beet ${ }^{(73,75)}$. Commercially available lateral flow strips are currently limited to few GM products, but strips that can simultaneously detect multiple proteins are being developed.

\section{Other Immunoassay Formats}

In addition to microplate ELISA and lateral flow devices, other immunoassay formats use magnetic particles as the solid support surface. The magnetic particles can be coated with the capture antibody and the reaction carried out in a test tube. The particles with bound reactants are separated from unbound reactants in solution by a magnet. Advantages of this format are superior kinetics and increased precision because the uniform particles are free to move in reaction solutions ${ }^{(74)}$. Advances are also being made in combining antibody methods with instrumental techniques. For example, in addition to the hyphenated method, such as immunoassay-mass spectrometry, considerable advances in relative observation of antibody binding to target molecules using biosensors have been reported ${ }^{(74)}$.

ELISA is the method of choice to screen for a particular GMO in raw material, semi-processed foods and processed ingredients, provided the expressed protein is not degraded and can be detected. However, because ELISA has lower detection power than PCR methods, it is less sensitive for testing finished food products with many ingredients, especially if the threshold for detection is low. Although protein-based tests are practical and effective, some GM products do not express a detectable level of pro$\operatorname{tein}^{(41)}$

\section{OTHER DETECTION METHODS}

\section{NIR Spectroscopy}

Certain genetic modifications may alter the fiber structure in plants, whereas no significant differences could be observed in the content of protein and oil (e.g. RR soybeans). These could be detected by near infrared spectroscopy (NIR) as reported by Hurburgh et al. ${ }^{(76)}$. Sample sets of RR and non-RR soybeans have been used to develop discriminate analysis calibrations for various models of near-infrared spectrometers. The results obtained by the 
three NIR instruments vary slightly, but are promising in all cases. However, the capacity of NIR to resolve small quantities of GMO varieties in non-GMO products is assumed to be low, as is true for the chromatographic methods.

NIR transmittance spectroscopy has been used by grain handlers in elevators in most of the world for nondestructive analysis of whole grains for the prediction of moisture, protein, oil, fiber and starch. Recently, the technique has been used in attempts to distinguish RRS from conventional soybean $^{(77)}$. In this study, spectral scans were taken from three Infratec 1220 spectrometers where whole-grain samples flew through a fixed path length. Locally Weighed Regression using a database of about 8000 samples was 93\% accurate for distinguishing RRS from unmodified soy. The advantages of this technique are: (1) it is fast (less than $1 \mathrm{~min}$ ), (2) sample preparation is not necessary because it uses whole kernels (about $300 \mathrm{~g}$ ), which are dropped into measurement cells or flow through the system, and (3) it is therefore cheap. The major disadvantage is that it does not identify compounds, thereby necessitating a large set of samples to generate spectra. This calibration dataset is then used to predict the GMO event. Thus, this method cannot be more accurate than the reference method used to build the model. Moreover, a calibration needs to be developed for each GMO to be predicted. Furthermore, although NIR is sensitive to major organic compounds (e.g. vibration overtones of $\mathrm{C}-\mathrm{H}, \mathrm{O}-\mathrm{H}$ and $\mathrm{N}-\mathrm{H}$ ), its accuracy is limited. For example, with respect to GMOs, it does not detect a change in DNA or a single protein, but much larger unknown structural changes, such as those linked to the parietal portion of the seed (e.g. lignin or cellulose) that are introduced by the presence of the new DNA.

\section{Chromatography}

Where the composition of GMO ingredients (e.g. fatty acids or triglycerides) is altered, conventional chemical methods based on chromatography can be applied for detection of differences in the chemical profile. This has been demonstrated with oils deriving from GM canola, for which high performance liquid chromatography (HPLC) coupled with atmospheric pressure chemical ionization mass spectrometry was applied to investigate the triglyceride patterns. The spectral identification was based on the diacylglycerols fragments and on the protonated triglyceride molecular ions. Quantification was performed using a flame ionization detector (FID). Comparing the triglyceride patterns, it could be observed that the oils of the GM canola varieties had an increased content of triacylglycerols, showing more oxidative stability for high stearic acid canola oil as well as for high lauric acid canola oil. This result is consistent with results obtained in previous oxidative stability studies on soybean and high oleic acid canola oils by using HPLCFID $^{(78)}$. In addition, the fatty acid compositions have been measured using gas chromatography coupled with FID to support the HPLC results.

However, it must be stressed that this methodology is only applicable when significant changes occur in the composition of GM plants or derived products. Moreover, it is a qualitative detection method rather than a quantitative method. For example, small additions of GM canola oil with an altered triglyceride composition to conventional canola oil will most probably not be detected given the natural variation of ingredient patterns.

\section{CONCLUSIONS}

To respond to the regulations of every country, a tiered approach might be employed, starting with qualitative PCR for GMO detection. If no GMOs are detected with a validated qualitative method, the product(s) would be evaluated for the presence of protein. If no protein is detected, the product is presumed not detectable. If the qualitative PCR shows a positive result, the product is considered as "non-approved GMO", and a validated Q-PCR is used to detect the level of GMO. If the GMO level is above the established threshold, the product is labeled as "non-approved GMO", but if below the threshold, the product needs not be labeled. The high sensitivity and specificity of Q-PCR methods and their flexibility with different food matrices make them suitable for detecting GMOs at low thresholds in various foods.

The greatest uncertainty of using DNA-based assays, as for protein-based methods, is that not all products derived from GM foods (e.g. refined oil) contain enough DNA. In addition, heating and other processes associated with food production can degrade DNA. Similarly, if GMO is expressed on a relative basis (i.e. \% GMO), it is important to know whether the estimate is based on total DNA from all sources, or on the basis of analyzed product DNA. This approach known as "genetic equivalence", which is sound and pragmatic, is correlated with results of studies where GMO content is expressed as a percentage of mass ${ }^{(23)}$. QPCR might be applied best at early stages in the food production chain. Using the genome equivalent approach to assess the GMO content of food ingredients and tracking the ingredients used should allow accurate estimation of GMOs. This approach is also consistent with current food-labeling regulations of the countries that focus on ingredients, and is also applicable to finished products containing more than one GMO-derived ingredient.

\section{REFERENCES}

1. Pinstrup-Anderson, P., Pandya-Lorch, R., and Rosegrant, M. W. 1999. World food prospects: Critical issues for the early twenty-first century. International Food Policy Research Institute.

2. FAO. 2000. Agriculture: Towards 2015/30, Technical Interim Report. FAO.

3. United Nations. 1999. World Population Prospects: The 1998 Revision, New York.

4. FAO. 2001. The state of food insecurity in the world. FAO.

5. Ku, T. Y. 2001. Overview of food demand and food pro- 
duction in the future. Issues in the Management of Agricultural Resources. Food \& Fertilizer Technology Center for the Asian and Pacific Region, pp. 25-38.

6. Diaz-Bonilla, E. and Robinson, S. 2001. Biotechnology, trade and hunger, in IFPRI 2000-2001 Annual Report. International Food Policy Research Institute.

7. ISAAA. 2002. Annual Report. ISAAA.

8. ETC Group. 2001. Globalization Inc. Communique \# 71.

9. Fernandez-Cornejo, J and Mcbride, W. D. 2002. Adoption of Bioengineered Crops. Agricultural Economic Report, No. 810. USDA, ARS.

10. Hategekimana, B. 2001. Corn and soybeans grown from genetically modified seed are not unusual, vista on the agri-food industry and the farm community, March 2001 Issue pp. 5-7. Statistics Canada

11. Carpenter, J. E. 2001. Comparing Roundup Ready and conventional soybean yields, 1999. National Center for Food and Agricultural Policy Research Paper.

12. Shoemaker, R. ed. 2001. Economic Issues in Agricultural Biotechnology. Agricultural Economic Report, No. 762. USDA, ARS.

13. FAO. 2002. Declaration of the world food summit: five years later. World food summit: five years later, Rome, Italy, June 10-13, 2002

14. Randell, A. 2001. International Consensus-Building on Biotechnology and Food safety: The Work of the Codex Alimentarius Commission, Paper presented at the New Biotechnology Foods and Crops: Science, Safety and Society Bangkok Conference, July 10-12, 2001.

15. Serageldin, I. and Persley, G. J. 2000. Promethean Science: Agricultural Biotechnology, the Environment and the Poor. CGIAR.

16. Internet 2001. http://www.doh.gov.tw/english/food/ biotech/Guidance.htm

17. Internet 2001. http://www.doh. gov.tw/english/food/ biotech/Biotechnology.htm

18. Dickson, D. 2001. Public Attitudes to Biotechnology: Where are they heading? Paper presented at the New Biotechnology Foods and Crops: Science, Safety and Society Bangkok Conference, July 10-12, 2001.

19. Gaskell, G. 1999. Worlds apart? The reception of genetically modified food in Europe and the U.S. Science 285: 384-386.

20. Haslberger, A.G. 2000. Monitoring and labeling for genetically modified products. Science 287: 431-432

21. US National Academy of Sciences. 2000, Genetically Modified Pests-Protected Plants: Science and Regulations, National Academy Press

22. Butler, D. 1999. Long-term effect of GM crops serves up food for thought. Nature 398: 651-656.

23. Yates, K., ed. 1999. Detection Methods for Novel Foods Derived from Genetically Modified Organisms, ILSI Europe.

24. Gupta, A. 2000. Governing trade in genetically modified organisms. The Cartagena Protocol on Biosafety. Environment 42: 22-23.
25. Schreiber, G.A. 1999, Challenges for methods to detect genetically modified DNA in foods. Food Control 10: 351-352.

26. Serageldin, I. 1999. Biotechnology and food security. Science 285: 387-389.

27. Gilbert, J. 1999. Sampling of raw materials and processed foods for the presence of GMOs. Food Control 10: 363-365.

28. USDA (United States Department of Agriculture) 1995. Grain Inspection Handbook, Grain Inspection, Packers and Stockyards Administration (GIPSA), Federal Grain Inspection Service (FGIS), Washington, DC.

29. Ministry of Health, Labour and Welfare, Japan, Testing for foods produced by recombinant DNA techniques, http://www.mhlw.go.jp/english/topics/food/ sec051a.html

30. Ahmed, F. E. 1999. Safety standards for food contaminants. In Environmental Contaminants in Food (Moffat, C.F. and Whittle, K.J., eds), Ch. 13 pp. 500-570, Sheffield Academic Press.

31. Internet 2001. http://www.usda.gov/gipsa/biotech/sampling-plan 1.xls

32. Internet 2001. http://www.usda.gov/gipsa/referencelibrary/directi/9181-1.pdf

33. Sambrook, J. and Russel, D. 2000. Molecular Cloning: A Laboratory Manual (3rd edn), Cold Spring Harbor Laboratory Press.

34. Ahmed, F. E. 1995. Application of molecular biology to biomedicine and toxicology. J. Environ. Sci. Health C11, $1-51$.

35. Hertzberg, M. 2001. cDNA microarray analysis of small plant tissue samples using cDNA target amplification protocols. Plant J. 25: 585-592.

36. Hemmer, W. 1997. Foods derived from genetically modified organisms and detection methods. BATS-Report 2/1997, Agency for Biosafety Research and Assessment of Technology Impacts of the Swiss Priority Programme Biotechnology of the Swiss National Science Foundation, Basel, Switzerland.

37. Vroh, Bi I., Harvengt, L., Chandelier, A., Mergeai, G., Du Jardin, P. 1996. Improved RAPD amplification of recalcitrant plant DNA by the use of activate $d$ charcoal during DNA extraction.Plant Breeding 115: 205-206.

38. Zimmermann, A., Lüthy, J., Pauli, U. 1998. Quantitative and qualitative evaluation of nine different extraction methods for nucleic acids on soya bean food samples. $\mathrm{Z}$ Lebensm Unters Forsch 207: 81-90.

39. Pauli, U., Liniger, M., Zimmermann, A. 1998. Detection of DNA in soybean oil. Z Lebensm Unters Forsch 207: 264-267.

40. Hellebrand, M., Nagy, M., Mörsel, J. T. 1998. Determination of DNA traces in rapeseed oil. Z Lebensm Unters Forsch A 206: 237-242.

41. De Palma, A. 2001. Capillary electrophoresis. Genet. Eng. News 21: 21-22.

42. Tinker, N. A. 1993. Random amplified polymeric DNA and pedigree relationship in spring barley. Theor. Appl. 
Genet. 85: 976-984.

43. Meyer, R. 1994. Detection of pork in heated meat products by polymerase chain reaction. J. AOAC Int. 77: 617-622.

44. Gasch, A. 1997. Detection of genetically modified organisms with the polymerase chain reaction: potential problems with food matrices. In Foods Produced by Modern Genetic Engieering (Schreiber, F.A. and Bögl, K.W., eds) 2nd Status Report, pp. 90-79, BgVV-hefte.

45. Meyer, R. 1999. Development and application of DNA analytical methods for the detection of GMOs in food. Food Control 10: 391-399.

46. Lipp, M. 1999. IUPAC collaborative trial study of a method to detect genetically modified soybeans and maize in dried powder. J. AOAC Int. 82: 923-928.

47. Hill, M. 1999. Identification of the aph IV gene from protoplasts-derived maize plants by a simple nonradioactive DNA hybridization method. In Vitro Cell. Dev. Biol. 35: 154-156.

48. Van Hoef, A. M. A. 1998. Development and application of a selective detection method for genetically modified soy and soy-derived products. Food Addit. Contam. 15: 767-774.

49. GeneScan Europe 2001. GMO Chip: Test Kit for the Detection of GMOs in Food Products, Cat. No. 5321300105, Bremen, Germany.

50. Anonymous 1998. Council regulation (EC) No. 1139/98, concerning the compulsory indication of the labelling of certain foodstuffs produced from genetically modified organisms. Official J. Eur. Communities: Legislation 159: 4-7.

51. Hübner, P. 1999. Quantitation of genetically modified organisms in food. Nat. Biotechnol. 17: 1137-1138.

52. Chen, L. H. 2002. GMO regulation in Taiwan. Proceedings International Workshop on Impacts and Biosafety of Genetically Modified Agricultural Products. (Pan, T. M. ed) pp. 61-68. FFTC/ASPAC.

53. McPherson, M. J. and Møller, S. G. 2000. PCR, Springer-Verlag.

54. Studer, E. 1998. Quantitative competitive PCR for the detection of genetically modified soybean and maize. $\mathrm{Z}$. Lebensm.-Unters. Forsch. 17: 207-213.

55. González, I., García, T., Fernández, A., Sanz, B., Hernández, P. E., Marín, R. 1999. Rapid enumeration of Escherichia coli in oysters by a quantitative PCRELISA. J Appl Microbiol 66: 231-236.

56. Landgraf. A., Reckmann, B., Pingoud, A. 1991. Determination of GMO in soybean. Anal Biochem 198: 86-91.

57. Taoufik, Y., Froger, D., Benoliel, S., Wallon, C., Dussaix, E., Delfraissy, J. F., Lantz, O. 1998. Quantitative ELISA-polymerase chain reaction at saturation using homologous internal DNA standards and chemiluminescence revelation . Eur Cytokine Netw 9: 197-204.

58. Heid, C. A. 1996. Real-time quantitative PCR. Genome Res. 6: 986-994.
59. Official Collection of Test Methods. 1997. Detection of a genetic modification of potatoes by amplification of the modified DNA sequence using the polymerase chain reaction $(\mathrm{PCR})$ and hybridization of the PCR product with a DNA probe. German Federal Foodstuffs Act Food Analysis, article 35, L 24.01-1. Beuth, Berlin Köln.

60. Ahmed, F. E. 2000. Molecular markers for early cancer detection. J. Environ. Sci. Health C18: 75-125

61. Hagen, M. and Beneke, B. 2000. Detection of genetically modified soy (Roundup-Ready) in processed food products. Berl. Munch. Tierarztl. Wochenschr. 113: 454-458.

62. Vaitilingom, M. 1999. Real-time quantitative PCR detection of genetically modified maximizer maize and Roundup Ready soybean in some representative foods. J. Agric. Food Chem. 47: 5261-5266.

63. Official Collection of Test Methods. 1998. Detection of a genetic modification of soybeans by amplification of the modified DNA sequence by means of the polymerase chain reaction (PCR) and hybridization of the PCR product with a DNA probe. German Federal Foodstuffs Act-Food Analysis, article 35, L 23.01.22-1. Beuth, Berlin Köln.

64. Official Collection of Test Methods. 1999. Detection of a genetic modification of tomatoes by amplification of the modified DNA sequence using the polymerase chain reaction (PCR) and hybridization of the PCR product with a DNA probe. German Federal Foodstuffs ActFood Analysis, article 35, L 25.03.01. Beuth, Berlin Köln.

65. Schweizerisches Lebensmittelbuch. 1998. Molekularbiologische Methoden. In: Bundesamt für Gesundheit (ed) Eidgenössische Drucksachen und Materialzentrale, Bern, Switzerland, chap 52B.

66. AFNOR 2000. Foodstuffs-Detection and quantification of genetically modified vegetal organisms and derived products-Part 1-Guidelines and requirements. Association Française de Normalisation, Paris, France.

67. Anklam, E., F. Gadani, P. Heinze, H. Pijnenburg, G. V. D. Eede. 2002. Analytical methods for detection and determination of genetically modified organisms in agricultural crops and plant-derived food products. Eur Food Res Technol 214: 3-26.

68. Brett, G. M. 1999. Design and development of immunoassays for detection of proteins. Food Control 10: 401-406.

69. Stave, J. W. 1999. Detection of new or modified proteins in novel foods derived from GMO-future needs. Food Control 10: 367-374.

70. Cochet, O. 1998. Immunological Techniques Made Easy, John Wiley.

71. Rogan, G. J. 1999. Immunodiagnostic methods for selection of 5-enolpyruvyl shikimate-3-phosphate synthase in Roundup Ready ${ }^{\circledR}$ soybeans. Food Control 10: 407-414.

72. Ahmed, F. E. 2002. Detection of genetically modified organisms in foods. Trends in Biotech. 20: 215-223. 
73. Lipton, C. R. 2000. Guidelines for the validation and use of immunoassays for determining of introduced proteins in biotechnology enhanced crops and derived food ingredients. Food Agric. Immunol. 12: 153-164.

74. Brett, G. M. 1999. Design and development of immunoassays for detection of proteins. Food Control 10: 401-406.

75. Fagan, J. 2001. Performance assessment under field conditions of a rapid immunological test for transgenic soybeans. Int. J. Food Sci. Technol. 36: 1-11.

76. Hurburgh, C. R., Rippke, G. R., Heithoff, C., Roussel, S. A., Hardy, C. L. 2000. Detection of genetically modified grains by near-infrared spectroscopy. Proceedings PITTCON 2000-Science for the 21st Century, \#1431. New Orleans, La. 12-17 March 2000 or Internet 2000. http://pittcon24857.omnibooksonline.com/

77. Roussel, S. A. Detection of Roundup Ready soybean by near-infrared spectroscopy. Appl. Spectrosc. (in press).

78. Byrdwell, W. C., Neff, W. E. 1996. Analysis of genetically modified canola varieties by atmospheric pressure chemical ionization mass spectrometric and flame ionization detection. J Liq Chromatogr Relat Technol 19: 2203-2225.

\title{
基因改造生物之現況與檢驗
}

\author{
潘子明 \\ 國立台灣大學 農業化學系 \\ 臺北市 116 羅斯福路四段一號 \\ (收稿: September 30, $2002 ;$ 接受: November 22, 2002)
}

摘 要

基因改造食品之生產集中在少數國家，以 2001 年為例，百分之九十九集中在四個國家，美國佔百分之 六十八, 阿根廷百分之十一點八, 加拿大百分之六, 中國大陸百分之三。以種類分, 最重要四類及其全世界 基因改造食品生產面積百分比分別為大豆（百分之六十三）、玉米（百分之十九）、棉花（百分之十三）及油 菜子（百分之五）。基因改造大豆及玉米生産面積各佔其全世界生產面積的百分之四十六與百分之二十。 2001 年生產之最重要的基因改造作物品系百分之七十七為耐除草劑作物, 而Bt玉米則佔百分之十一。

由於全球均有檢驗作物、食品中基因改造生物之需求，使得可靠又準確檢驗基因改造成分之方法極為迫 切。本文探討以蛋白質為檢驗基礎的西方墨點法、酶素連結免疫吸附法、檢驗試條及南方墨點法; 以及以 DNA 為基礎的定性聚合酶鏈反應法、定量聚合酶鏈反應法、即時聚合酶鏈反應法及稀釋聚合酶鍕反應法。 如果改造基因序列不明時, 近紅外線光譜法可用於檢驗基因改造成分。檢驗中要探討篩選、鑑定及確認之有 效性, 以免產生偽陽性, 並符合不再使用基因標示、特定調控序列之大量使用以及基因改造食品數目大幅增 加之需求。

關鍵詞：基因改造生物、基因改造食品、西方墨點法、酵素連結免疫吸附法、檢驗試條、南方墨點法、定性 聚合酶鏈反應法、定量聚合酶鏈反應法、即時聚合酶鏈反應法、稀釋聚合酶鏈反應法 